Article

\title{
How to Achieve Sustainable Development of Mobile Payment through Customer Satisfaction-The SOR Model
}

\author{
Su-Chang Chen ${ }^{1}$, Kuo Cheng Chung ${ }^{1, *(\mathbb{D})}$ and Ming Yueh Tsai ${ }^{2}$ \\ 1 Department of Marketing and Logistics Management, National Penghu University of Science and \\ Technology, Magong City, Penghu County 88046, Taiwan; csc@npu.edu.tw \\ 2 Land Bank of Taiwan, Taipei City 10047, Taiwan; a0989411830@gmail.com \\ * Correspondence: d9732004@gmail.com
}

Received: 15 October 2019; Accepted: 6 November 2019; Published: 11 November 2019

\begin{abstract}
In recent years, due to smartphones being more popular and the wireless network infrastructure improving, individuals are no longer constrained by the workflow on personal computers. Therefore, business operators are constantly launching new mobile application services for everyday life. This study mainly explores how mobile payment adopts the determinants, and adds utilitarian value, hedonic value and salesperson performance as antecedences to understand whether utilitarian value, hedonic value and salesperson behavior can affect satisfaction through determinants, as well as to understand consumers' mobile payment usage intention through the stimulus-response model. The research objectives of this study are mainly mobile payment users in Taiwan. 425 valid questionnaires were received. This study uses a structural equation model to analyze the data. This study's results indicate that utilitarian value, hedonic value and salesperson selling behaviors positively affects customers' satisfaction, which customers' satisfaction positively affects mobile payment usage intention. The research results could provide mobile payment operators with references in the design and implementation of the mobile payment and application process, thereby accelerating the popularization of mobile payment.
\end{abstract}

Keywords: stimulus-response model; utilitarian value; Hedonic value; salesperson selling behaviors; customer satisfaction

\section{Introduction}

Research Background and Motives

With the popularization of the $4 \mathrm{G}$ mobile network and the diversified development of smart phone applications, the time spent by Taiwanese on mobile phones is increasing year by year. According to the report of the Institute for Information Industry, $51.5 \%$ of the people belong to moderate users of mobile phones, while $28.1 \%$ spend more than $5 \mathrm{~h}$ on mobile phones every day, making them heavy users [1]. It is worth noting that entertainment content has become the focus of the use of these mobile phones.

Consumers can pay for things in stores by scanning the bar codes, or sensing through their mobile phones, as long as their mobile phones are bound to their credit cards, bank accounts or electronic wallets, sparing them the trouble of carrying credit cards and cash.

According to the estimation of Statista, an international research institute, global mobile payment transactions will grow from 391.4 billion USD in 2018 to 1 trillion USD in 2021 and 1.3 trillion USD in 2022, with an annual composite growth rate (CAGR) of 35.7\%, while the number of global mobile payment users is looking forward to growing up to $970,000,000$ by 2022 , which number was $530,000,000$ in 2018, and its annual composite growth rate is $16.2 \%$ [2]. Pursuant to the statistical data of the 
Institute for Information Industry, the penetration rate of mobile payment in 2017 is $39.7 \%$, which is a growth in multiple compared with 19\% in 2015.

In response to consumers' willingness to use mobile payments, many studies suggest that strategies which improve the usability and ease of use of mobile payments enhance customer value, and the reduced perceived risks will increase the customers' willingness to use mobile payments. The survey of the Institute for Information Industry [3] finds that about 39.7\% of Taiwanese smart phone users used mobile payment in 2017, and consumers' perception of mobile payment increased from $84 \%$ in 2016 to $91 \%$ in 2017 . The above data show that consumers' experience and perception of mobile payment is significantly improved. However, the proportion of mobile payment is still low compared with other payment markets. Although the acceptance of mobile payment among the public is gradually increasing, mobile payment has not reached the expected popularity. With the advent of the Banking 4.0 era, the behavioral patterns of financial consumers changes dramatically. Key factors for progress include consumers' perceived value, as it can attract new consumers and retain the original consumers [4]. Cognition and emotion would affect consumers' willingness to use technology services [5]. From the perspective of system design, consumers' use of mobile payment seems to bring more convenience to their life and it deserves to be their preference. Lee et al. (2004) points out that personal anxiety about technology will affect users' willingness to use mobile payment [6]. So as to achieve the popularization of mobile payment, we should not only strengthen the demand side (the perceived value of consumers), but also consider the supply side (the willingness of stores to provide good mobile payment services, including the salesperson's behaviors). The main purpose of many companies launching mobile pay is to utilize the convenient consumption model to assist the integration of online and offline virtual channels, cultivating loyal member customers and also grasping the contours of consumers' behavior based on consumers' big data. Then they shall launch products that are closest to customers' needs and propose the marketing strategy, so that the company can grasp the customers' consumption trends and respond to the market environment.

In review of literatures on the research of mobile payment use intentions in recent years, Lee et al. (2009) studies the interaction between the mobile payment platform and customers, pointing out that consumers will have an impact on network externality [7]. Consumers tend to use mobile payment under peer influence, while their purchase decisions are not easily subject to the influences of web advertising and promotion. Through the analysis based on innovation diffusion theories, Sharma (1999) brings up that trust is the most significant factor in mobile payment [8]. Customers make decisions on the use of mobile payment mainly according to the reputation, convenience and specifications of the payment platform. In the past studies, there is rare research on the intention to use mobile payment from the point of view of customer demand, except for Wang (2008) from interviews with mobile payment users' switching behavior, based on the Push-Pull-Mooring Theory, which came to the finding that privacy concerns are the determinant on consumers' decisions about whether to use the mobile payment [9]. Our study aims to understand the impacts of environmental stimulus and internal psychological state on consumers' intentions to use mobile payment from the view of points of customer demand, in order to compensate for the lack of previous literature on mobile payment, and to achieve the goal of sustainable operation. This study uses a stimulus-response model to analyze customers' consumption psychology.

\section{Literature Review}

\subsection{Mobile Payment}

As of late, with the consistent innovation and developing of Internet technology and e-commerce, mobile devices have become an inseparable companion of people in their daily life. They can use smart devices in their hands for socializing, playing games, sending and receiving e-mails, browsing messages, taking photos, or even shopping. Among them, the payment method has changed from simple cash or credit to mobile payment. Therefore, more and more people worldwide are using mobile 
payment. According to EMarketer (2018) research, 34.9\% of smart phone users will pay through mobile phones in retail channels at least every six months [10]. Advances in mobile payment technology have reduced technology barriers to mobile payment, and coupled with the rise of financial service Apps and the expanding accessibility of mobile devices, we believe that mobile payment will become more common and simple in the future [11]. Consumers can apply to the credit card issuing bank for this e-wallet. The e-wallet stores users' profiles, facilitating consumers to use it online. The operating mechanism is that the buyer's credit information will be encrypted before transmitting it to the seller's server. After the bank receives the encrypted data, the confirmation message is also encrypted into the credit card data, and this then transmits to the relevant bank network. Mobile payment is to use a Smartphone as an electronic wallet, so that consumers can use several services and pay for physical goods without using coins or credit cards. There are five types of mobile payment methods: SMS-based transfer payments, mobile bill payments, wireless application protocol payments (WAP), application payments (APP) and Near-field communication payments (NFC).

Mobile payment can be divided into two different types: Remote payment and short-range payment. Remote payment allows consumers to access financial accounts remotely, and can remit money or get other online services by using mobile devices and mobile websites, including mobile banking, mobile network payment, and so on [12]; short-range payment is also known as mPOS payment, which refers to payments that occur when customers and merchants are very close. In this type of payment, the vouchers of transactions displayed on cell phones and traded over short distances uses barcode scanning or radio frequency identification (RFID) technology [13]. In other words, consumers and physical store owners must make transactions face to face. Commodity trade and services occur in adjacent fields, for example, paying for transport tolls, dinner or shopping payment services in physical stores. Offline physical transactions use mobile tools and the merchants' equipment to transmit data to complete the cash flow. At present, there are two common ways of information communication, namely NFC sensing and bar code scanning. Mobile payment with NFC sensing technology requires consumers to install the mobile payment App on their mobile devices and store a variety of payment tools. Businessmen must build POS terminals for NFC payment [14]. This study considers mobile payment as a kind of payment, with smart phones as the tools to complete the transaction for purchases in physical stores, by using non-cash financial instruments with certification steps through specific transmission technologies or devices.

\subsection{SOR (Stimulus-Organism-Response) Framework (Stimulas-Response Model)}

Mehrabian and Russell (1974) originally proposed Stimulus-Organism-Response (S-O-R) from environmental psychology [15]. In the S-O-R framework, it is assumed that stimulus has an impact on the emotional state of an individual. This internal processing involves the individual's cognitive and emotional responses, such as the perception of stimuli; response represents the individual's behavioral outcomes, which can show that SOR is a physical and intangible form [16]. SOR stimulates individual's emotional and cognitive state through environmental cues, leading to certain behavioral outcomes [17]. Using the SOR model in the study of consumer behavior is helpful to distinguish environmental stimuli from consumers' internal and external behavior. Therefore, this S-O-R framework is considered to be a popular psychological theory in consumer behavior research [18].

The target of this study is to scrutinize consumers' consumption behavior of mobile payment from their cognitive and emotional responses through the S-O-R framework, the Stimulus factors consumer's hedonic value and utilitarian value and salesperson selling behaviors during this study. The reason is that consumers are exposed to the situational stimulus in the use of mobile payment in physical stores. Organism refers to the users' emotional and cognitive state, including their views, experiences and evaluations, and its factor selected in this study is satisfaction. Finally, Response is the intention of use. The study of Hossain et al. (2018) using SOR for mobile payment is the only one that uses stimulus-organism-response (SOR) as the study framework to understand the customer's purchase intentions and satisfaction of using mobile payments [19]. 
On the whole, when consumers are using mobile payment, the stimulation of perceived value which comprises hedonic value and utilitarian value and salesperson selling behaviors will affect their inner cognitive state (satisfaction) and their behavioral response (intention to use mobile payment).

\subsection{Utilitarian Value}

Value can influence consumers' views and considerations in purchasing products. In the same shopping situation, consumers with different shopping values will show different consumption behaviors [20]. Perceived value has two consumption values: Hedonic value and utilitarian value [21]. These two levels of value gave a complete picture of consumers' values [22]. Babin et al. (1994) points out that the utilitarian value represents that the usefulness, functionality and cognition of the tools and tasks related to consumption are essentially means to achieve goals [21]. Overby and Lee (2006) argue that the utilitarian value is the consumer's assessment of the cost and substantial advantages of products, services and prices after considering their characteristics [23]. Lowe and Alpert (2015) point out that the consumers' product perceptions, such as concepts, technological novelty and comparative advantages, all affect their hedonic and utilitarian values [24]. Overby and Lee (2006) point out that consumers mostly consider rational factors, i.e., judgment of economic benefits in terms of money, convenience and time cost [23].

\subsection{Hedonic Value (HV)}

Jong et al. (2010) believe that consumers with hedonic motivation would give themselves reasons to indulge themselves in shopping, with reasons including the elements of fun, happiness, joy and excitement [25]. Hedonism is related to the desire to pursue happiness and self-realization. Babin et al. (1994) regards shopping as enjoyment, which can relax the mood, relieve the pressure in the real life, and arouse a happy response naturally in the inner heart [21].

Roy and $\mathrm{Ng}$ (2012) argue that hedonic value is the comparatively strong emotion that consumers usually have toward a product [26]. They would consider all kinds of feelings that a product can bring, and evaluate the costs they would pay and the experienced benefits they would get, such as the feelings of pleasure, enjoyment and escaping from reality [23]. Soman (2003) puts forward the concept of payment transparency and regards mobile payment as an intangible way of payment which indirectly reduces customers' pain in payment, and thus reduces their negative emotions, so that consumers may pay more attention to the benefits of purchasing products than to the costs of using mobile devices to pay for them [27-29]. In terms of the development of hedonic value, Chitturi et al. (2007) put forward the principle of "hedonic advantage", that is, when all products to be purchased meet or exceed the standard value of utility and hedonism, consumers will pay more attention to hedonic benefits when choosing products [30]. Chitturi et al. (2008) indicate that consumers' pleasure could be generated through the promotion activities of stores, or when the products themselves could satisfy consumers' hedonic demands [31].

\subsection{Salesperson Selling Behaviors}

In the retail environment, the interaction between salesperson and customers is an important behavioral relationship. Jones et al. (2005) point out that because of the rapid changes in information technology and customer preferences, consumers' requirements for products and services and their expectations for salespersons are getting higher and higher [32]. Some consumers like to interact with salespersons when shopping, thereby establishing business friendship between salesmen and consumers, which often involves emotional elements [33]. Many enterprises begin to emphasize the customer-oriented marketing concept. How to improve customer value, customer satisfaction, service quality and retain customers has become the direction that enterprises must think about [34].

Service behavior is defined as the behavior of a salesperson after the initial point of sale by Ahearne et al. (2007) [35]. This ongoing behavior aims at cultivating and developing exchange relationships, and identifies five aspects of the salesperson's service behavior: Diligence, information 
communication, induction, sportsmanship and empathy. Darian et al. (2005) defines salesperson selling behavior as the consumers' feelings brought by the interaction between the salesperson and consumers in the shopping procedure [36]. Salespersons assume a significant job in sales, as they contact and interact with customers on behalf of the manufacturers. The success of marketing strategy mainly depends on the salesperson [37]. For consumers, the friendliness of salespersons has an important impact on whether they could feel comfortable or stress-free during the shopping process. Rapp et al. (2014) interpret that a salesperson is like a knowledge broker, whose important job is to obtain information about their merchandise and industries, in order to explain and resolve customers' matters [38]. Therefore, salespeople should constantly enrich their knowledge about new products, so as to make an adequate product introduction to customers. Meanwhile, if the salesperson responds to the information needed by the customer in time, it will help the customer save time cost, and avoid negative emotions. Sharma (1999) points out that if retailers want to improve customer service, they should pay attention to the salesperson's selling behaviors, as when consumers feel the positive emotions conveyed by the salesperson, the message transmission and persuasion will be improved [8]. Lee and Dubinsky (2003) believe that not only the store environment will affect customers' purchasing mood, but the interaction between salespersons and customers will also promote the customers' purchasing mood [39]. With technological advances and rapid changes, consumers' unfamiliarity with the use of equipment may inhibit their adoption of the equipment. Friendly salespeople should use sales service technology to help inexperienced consumers to extend their consumer experience rather than to act as barriers.

\subsection{Mobile Payment Usage Intention}

The Rational Behavior Theory (TRA) proposed by Fishbein and Ajzen (1975) holds that we can predict individual behavior, and behavioral intention can also influence individual behavior, that is too say, the actual behaviors can be predicted through behavioral intention, which is a method of people's intention to engage in a particular behavior [40]. The key indicator in measuring the use of information technology is Behavioral intention, and it is the basis for developing information technology as well.

Behavioral intention is an individual's belief in what he wants to do in certain situations [41]. Zeithaml et al. (1996) divide behavioral intention into positive intention and negative intention. When consumers have positive intention, they will generate positive word-of-mouth, and then recommend products or services to their friends and relatives; if they have negative intention, they may choose to change products or reduce the number of purchases [42]. When behavioral intention is applied to the degree of an individual's willingness to use the technology information system in the future, that is, when an individual intends to use the system subjectively, he has generated the usage intention [43]. Consumers' usage intention is related to their experience of trying the products or services, as well as the continuous of consumers to use the products or services if they have positive usage experience [44].

A research on the usage intention of interactive information is proposed by Lin et al. (2008), and it states a model which shows that the usage intention is positively affected by satisfaction. Usage intention is usually considered to be as a prior variable for consumers' actual use of a mobile service $[45,46]$.

\section{Research Design}

\subsection{Research Structure}

This research is based on the S-O-R framework, supplemented by the two consumption values (hedonic value and utilitarian value) proposed by Babin et al. (1994), and combined with the external factor of salesperson selling behavior, which are integrated into the three main constructs of "utilitarian value", "hedonic value" and "salesperson selling behavior" as the external stimulus influencing 
individuals (stimulus), which further influences the consumers' mobile payment usage intention (response) by influencing customer satisfaction (organism) [21].

\subsection{Hypothesis Deduction}

Customers' perceived value originates from their personal experience and interaction with the products or services [47]. Understanding the value of products or services from a user's perspective is long considered a successful customer strategy, and is usually related to the overall business performance [48]. Terpstra and Verbeeten (2014) find that many studies show that the relevance between perceived value and customer satisfaction, along with customers' perceived service value, positively affects customer satisfaction [49]. According to the past literature, empirical studies of traditional retailers have confirmed that perceived value positively affects the customers' satisfaction in most cases, and similar conclusions have been drawn from researches on online shopping websites and e-commerce $[50,51]$. In light of the above literature, we deduce some hypotheses listed in the following on the mobile payment context in this study:

H1. Utilitarian value has a positive impact on customer satisfaction.

Although the relative importance of hedonic value and utilitarian value is different, hedonic value may be regarded as the user's psychological needs compared with the basic functional needs of utilitarian value [52]. Past literatures show that hedonic value is an important factor affecting satisfaction [12]. Yoo et al. (2010) also propose that in the interactive relationship between suppliers and purchasers, customers experience intimate relationships, making e-commerce users happier [53]. According to the above literature, our study deduces the following hypothesis in mobile payment context:

\section{H2. Hedonic value has a positive impact on customer satisfaction.}

Mobile payment is a new technology for Taiwanese consumers. Every new technology must be considered from a consumer perspective before its launch. Therefore, the salesperson assumes a significant job in the promotion. When the consumer uses the electronic wallet, all the personal data can be integrated on one mobile phone. However, there are many banks and telecommunications companies that are actively investing in how to make the most adhesive with consumers through the relationship between salespeople and customers. The salesperson's behavior and attitudes directly affect consumers' satisfaction [19]. The interaction between salespersons and consumers is very important. Compared with competitors, assuming that the salespersons can offer consumers with more merchandises' knowledge, they will create higher added value for customers, which will affect the performance of their retail stores [36].

Lee and Dubinsky (2003) hold that the reliability, professionalism, empathy, friendliness, enthusiasm, similarity and professionalism of salespersons all affect customers' mood and satisfaction in their consumption, and then affect their purchase intention [39]. Amyx and Bhuian (2009) find that the customer evaluation of salesperson selling behavior reflects customers' satisfaction of the service and brand loyalty [54]. In addition, scholars support the concept that adaptive sales could have distinctive customer satisfaction, for example, supplier satisfaction, and satisfaction with services/products [55,56]. In light of the above literature, this study deduces the following hypothesis in the mobile payment context:

H3. Salesperson selling behaviors have a positive impact on customer satisfaction.

Practical value and hedonic motivation are important factors affecting consumers' online shopping, and are also important for repeat purchasing intention [22,57]. In the past literature, some scholars propose that cognition and emotion would influence consumers' willingness to use technology services [5]. In terms of mobile services, Pihlstrom and Brush (2008) propose that money, convenience 
and emotional value would influence repurchase intention [58]. In light of the above literature, this study deduces the following hypotheses in the mobile payment context:

H4. Utilitarian value has a positive impact on mobile payment usage intention.

H5. Hedonic value has a positive impact on mobile payment usage intention.

The salespeople of electronic payment are very important to the consumer because they have usefulness, emotion and security [19]. In addition, they can also understand consumers' needs and deliver the opinions of consumers to the company. The salesperson's empathy (cognition and emotion) and professionalism (sales wisdom and communication ability) have an impact on product sales. Salesperson's characteristics will affect consumers' repurchase intention [59]. Kennedy et al. (2001) also believes that salesperson's professional ability and sales skills will affect customers' satisfaction with salesperson and repurchase [60]. Haas and Kenning (2014) hold that salespersons have influences in determining customers by providing information [61]. The salesperson is also an important factor influencing purchase intention [62]. In light of the above literature, this study deduces the following hypothesis in the mobile payment context:

H6. Salesperson behaviors have a positive impact on mobile payment usage intention.

Satisfaction means the comprehensive evaluation of a service or a product after consumption, which includes the satisfaction degree at the cognitive and emotional levels. The satisfaction degree serves as a basis for the judgment of the successive consumers' behavioral intentions [63]. Customer satisfaction can lead to subsequent behavioral intention, like repurchase intention and behavioral intention $[64,65]$. Expectation uncertainty theory is universally used to disclose customer satisfaction [66]. Satisfaction comes from the comparison between the performance and expectation perception. On the assumption that the performance meets customer expectations, it is satisfactory; otherwise, when performance is lower than customer expectations, it is unsatisfactory. In addition, Chen et al. (2012) mentions that the subject of expectation uncertainty theory is that repurchase behavior depends on satisfaction [67]. Satisfied customers often tend to make positive word-of-mouth, and have a strong intention to keep using the service [68]. The research structure is shown in Figure 1. This study deduces the following hypothesis, in light of the above literature:

H7. Customer satisfaction has a positive impact on mobile payment usage intention.

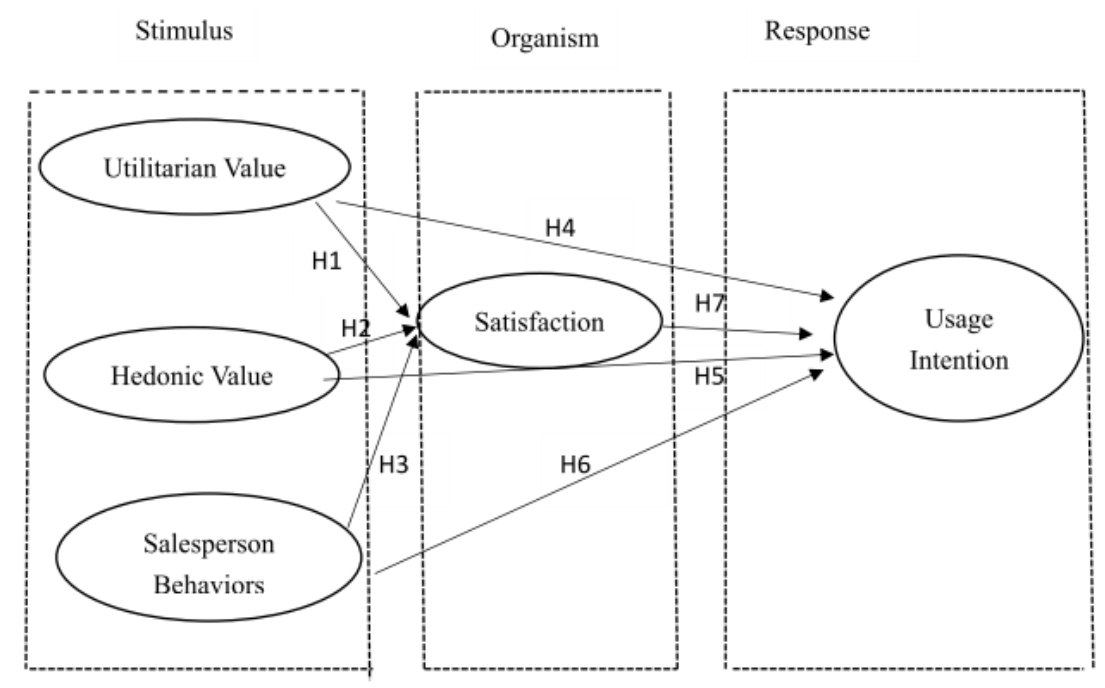

Figure 1. Research model. 


\subsection{Definition of Variables and Questionnaire Design}

The reason why we do this study is to scrutinize the relationship between the mobile payment users' satisfaction formed by their perceived utilitarian value, hedonic value and salesperson selling behaviors and their usage intention. This study adopts a method of investigation and research, and a structured questionnaire as the research tool. The subjects of this study are those who have experiences of using mobile payment in consumption in physical stores in Taiwan. Questionnaire data is received online. The content of the questionnaire was developed by collating the items of the scales already developed by experts and scholars that incorporate three segments: The initial segment is the experience of using mobile payment, the second segment consists of the questionnaire items, in order of utilitarian value, hedonic value and salesperson selling behaviors, customer satisfaction and mobile payment usage intention. Likert's 7-point scale was used as the measurement scale to quantify the data filled in by the respondents, ranging from 1 to 7 points, with 1 point representing "Strongly Disagree" and 7 points representing "Strongly agree", and finally, the third part is the basic data. Based on the research purpose and the need of research hypothesis, this study makes use of the operational characteristics of the structural equation model to measure the causal relationship between the measurement dimensions. The statistical software IBM SPSS AMOS 22 was used to make the model analysis and statistical software IBM SPSS Statistics 22 was used for statistical analysis of data (see Table 1).

Table 1. The demographic characteristics of the sample.

\begin{tabular}{ccc}
\hline & Frequency & Percentage \\
\hline Gender & & \\
Female & 201 & 47.3 \\
Male & 224 & 52.7 \\
Age & & \\
$20-$ & 5 & 1.2 \\
$21-30$ & 47 & 11.1 \\
$31-40$ & 181 & 42.5 \\
$41-50$ & 124 & 29.2 \\
$51+$ & 68 & 16.0 \\
Education & & \\
Diploma & 35 & 8.2 \\
Bachelor & 286 & 67.3 \\
Masters and Ph.D. & 104 & 24.5 \\
Income & & \\
20,000- & 13 & 3.0 \\
20,001-35,000 & 47 & 11.1 \\
35,001-50,000 & 128 & 30.1 \\
50,001-65,000 & 110 & 25.9 \\
65,001+ & 127 & 29.9 \\
\hline
\end{tabular}

\subsection{Sample Data}

In this study, samples were selected mainly from users who use mobile payment, mainly through an online questionnaire. The online questionnaires were mainly distributed through My Survey network platform. The questionnaires of this study were distributed in October 2018 and received in February 2019. The entire 526 questionnaires were received. After excluding 101 invalid questionnaires, there remained 425 valid questionnaires. The respondents of the questionnaires were consumers with experience in mobile payment in Taiwan in the past six months.

\subsection{Measurement}

In this study, analysis was made on five dimensions: Utilitarian value, hedonic value, salesperson selling behaviors, customer satisfaction and mobile payment usage intention by using Likert's 7-point 
Scale from 1 ("strong disagree") to 7 ("strong agreement"). The definition of utilitarian value is the consumers' assessment of the actual advantages and costs of using mobile payment services, with reference to [23]. The definition of Hedonic value is the degree to which consumers acquire emotional and sensory experience in using mobile payment services, with references to [68]. The salesperson selling behaviors are defined as the feelings brought to consumers by interaction between salesperson and consumer in the sales process, with reference to 36]. Customer satisfaction is the consumers' overall evaluation of use of the mobile payment service, with reference to [64]. Mobile payment usage intention is considered to be the willingness of people to pay through the mobile vehicle, with reference to $[69,70]$.

\section{Data Analysis}

\subsection{Reliability and Validity Analysis}

We use Harman's factor test method to conduct exploratory factor analysis (EFA) on all items in this study. Table 2 shows that five factors are extracted, and the explanatory power of the first factor is $34.265 \%$, which was less than $50 \%$. We can infer that there was no serious deviation in common method in the sample data of this study. In addition, we use single factor confirmatory factor analysis (CFA) for the test, which included all of the 25 items in the single-factor test. The results of the test indicate that the factor load level of 12 items exceeds 0.5 , and none of the items is significantly higher than the load level of 0.5 . The model values of this single factor validation analysis show that not all the constructional correlations in this study are derived from common method variations.

Table 2. Initial eigenvalues.

\begin{tabular}{cccc}
\hline Component & Eigenvalues & Variance (\%) & Cumulative Variance (\%) \\
\hline 1 & 8.566 & 34.265 & 34.265 \\
2 & 3.646 & 14.584 & 48.848 \\
3 & 3.003 & 12.012 & 60.860 \\
4 & 1.640 & 6.560 & 67.421 \\
5 & 1.408 & 5.630 & 73.051 \\
\hline
\end{tabular}

In terms of reliability, the combination reliability can be used as a test of internal consistency. It could be found through Table 3 that the values of combination reliability (CR) are from 0.846 to 0.9421 , and all of them are larger than 0.6 , indicating that each dimension of the measurement model has a certain degree of reliability. Table 3 shows the measurement model. Among them, the values of average variance extracted (AVE) were between 0.599 and 0.699 , all larger than 0.5 . In addition, the values of AVE open root sign are also larger than the correlation coefficient of each construct, which means that each construct has discriminant validity. This study conducts verification of discriminant validity according to the two criteria put forward by Gaski and Nevin (1985): If (1) the correlation coefficient between two constructs is less than 1 ; (2) the correlation coefficient between two constructs is less than the individual reliability coefficients Cronbach's $\alpha$, and thus it indicates that the two constructs have discriminant validity. In addition, using Fornell and Larcker's (1981) method, we got the third criterion for verification of the discriminant validity: (3) If the correlation coefficient of the two constructs is less than the square root of AVE, it indicates that the two constructs have discriminant validity [71,72]. In addition, we use SPSS 22.0 and AMOS 22.0 to analyze the correlation coefficient matrix of measurement variables in this study, with the analysis data received in the table, all of which conform to the above three criteria for verification of the discriminant validity, showing a good validity of each dimension. In Table 4, all CR values of the structural model are greater than 0.7 , which verifies that the measurement items of each dimension have internal consistency, and all AVE values are larger than 0.5 . Therefore, the proposed framework has convergent validity and the measurement model of this study has good convergent validity, discriminant validity and reliability. 
Table 3. Main statistics.

\begin{tabular}{|c|c|c|c|c|}
\hline \multirow{2}{*}{ Constructs } & \multicolumn{2}{|c|}{ MLE Estimates } & \multirow{2}{*}{$\begin{array}{c}\text { Composite } \\
\text { Reliability (CR) }\end{array}$} & \multirow{2}{*}{$\begin{array}{c}\text { Average of } \\
\text { Variance Extracted } \\
\text { (AVE) }\end{array}$} \\
\hline & $\begin{array}{l}\text { Factor Loading } \\
\qquad\left(\lambda_{x} / \lambda_{y}\right)\end{array}$ & $\begin{array}{l}\text { Measurement } \\
(\delta / \varepsilon)\end{array}$ & & \\
\hline Utilitarian Value & & & 0.889 & 0.068 \\
\hline UV1 & $0.824^{* * *}$ & 0.321 & & \\
\hline UV2 & $0.846^{* * *}$ & 0.284 & & \\
\hline UV3 & $0.816^{* * *}$ & 0.334 & & \\
\hline UV4 & $0.781^{* * *}$ & 0.390 & & \\
\hline Hedonic Value & & & 0.936 & 0.678 \\
\hline HV1 & $0.849^{* * *}$ & 0.279 & & \\
\hline HV2 & $0.793^{* * *}$ & 0.371 & & \\
\hline HV3 & $0.822^{* * *}$ & 0.324 & & \\
\hline HV4 & $0.827 * * *$ & 0.316 & & \\
\hline HV5 & $0.821 * * *$ & 0.326 & & \\
\hline HV6 & $0.813^{* * *}$ & 0.339 & & \\
\hline HV7 & $0.839^{* * *}$ & 0.296 & & \\
\hline Salesperson Behaviors & & & 0.882 & 0.599 \\
\hline SB1 & $0.721^{* * *}$ & 0.480 & & \\
\hline SB2 & $0.800^{* * *}$ & 0.360 & & \\
\hline SB3 & $0.815^{* * *}$ & 0.336 & & \\
\hline SB4 & $0.753^{* * *}$ & 0.433 & & \\
\hline SB5 & $0.765^{* * *}$ & 0.415 & & \\
\hline Satisfaction & & & 0.874 & 0.636 \\
\hline Sat1 & $0.849^{* * *}$ & 0.279 & & \\
\hline Sat2 & $0.839^{* * *}$ & 0.296 & & \\
\hline Sat3 & $0.792 * * *$ & 0.373 & & \\
\hline Sat4 & $0.699^{* * *}$ & 0.511 & & \\
\hline Usage Intention & & & 0.920 & 0.699 \\
\hline UI1 & $0.856^{* * *}$ & 0.267 & & \\
\hline UI2 & $0.775^{* * *}$ & 0.399 & & \\
\hline UI3 & $0.797^{* * *}$ & 0.365 & & \\
\hline UI4 & $0.856^{* * *}$ & 0.267 & & \\
\hline UI5 & $0.892^{* * *}$ & 0.204 & & \\
\hline
\end{tabular}

Note: UV: Utilitarian HV: Hedonic SB: Salesperson Behaviors US: Usage ${ }^{* * *} ; p<0.001$.

Table 4. Correlation matrix for measurement scales.

\begin{tabular}{cccccc}
\hline Constructs & Utilitarian Value & Hedonic Value & Salesperson Behaviors & Satisfaction & Usage Intention \\
\hline Utilitarian Value & 0.817 & & & & \\
Hedonic Value & 0.214 & 0.823 & & & \\
Salesperson & 0.132 & 0.166 & 0.773 & 0.797 & \\
Behaviors & 0.520 & 0.231 & 0.227 & 0.376 & 0.836 \\
Satisfaction & 0.356 & 0.572 & 0.284 & \\
Usage Intention &
\end{tabular}

\subsection{Model Fitness Analysis and Results}

The results of the basic fit criteria are that the error variance of the theoretical model is not negative, the load of standardization factors is not less than 0.50 or more than 0.95 , and all of them reach a significant level, and no higher standard errors are found (see Table 5). Therefore, the basic fitness of the research model should reach an acceptable level. The absolute fit measure index of the overall fitness of the model is as follows: $\chi^{2}=556.336$, d.f. $=265$, GFI $=0.908$, AGFI $=0.887$. Except that AGFI is slightly lower than the standard, various indices are in the criteria, and the index of incremental fit: NFI $=0.926, \mathrm{CFI}=0.908$, both within the acceptable range; the brief fit measurement index is: PNFI $=0.818$, PGFI $=0.740$, both within the acceptable range $(>0.500)$. On the whole, judging from all indices, in this study, the overall fitness of the theoretical model is good. 
The significance of the internal structural fitness of the model in evaluating this model's parameters, and the reliability of the indices and potential variables, can evaluated from whether the CR of the potential variables is above 0.70 , whether the AVE of the potential variables is above 0.5 , or whether the Individual Item Reliability is above the acceptable level of 0.5. Both the CR and AVE reach the standard value. On the whole, the evaluation results of the CR and AVE of potential variables show that this study's theoretical model has great fitness of internal structure.

Table 5. Standard coefficients and significance values.

\begin{tabular}{|c|c|c|c|c|c|}
\hline \multicolumn{3}{|c|}{ Paths } & \multirow{2}{*}{$\begin{array}{c}\text { Path Coefficients } \\
0.624^{* * *}\end{array}$} & \multirow{2}{*}{$\begin{array}{c}\text { Hypotheses } \\
\text { H1 }\end{array}$} & \multirow{2}{*}{$\begin{array}{c}\text { Test Results } \\
\text { Supported }\end{array}$} \\
\hline Utilitarian Value & $\rightarrow$ & Satisfaction & & & \\
\hline Hedonic Value & $\rightarrow$ & Satisfaction & $0.136^{* *}$ & $\mathrm{H} 2$ & Supported \\
\hline Salesperson Behaviors & $\rightarrow$ & Satisfaction & $0.320 * * *$ & $\mathrm{H} 3$ & Supported \\
\hline Utilitarian Value & $\rightarrow$ & Usage Intention & $0.173^{* *}$ & $\mathrm{H} 4$ & Supported \\
\hline Hedonic Value & $\rightarrow$ & Usage Intention & $0.528 * *$ & H5 & Supported \\
\hline Salesperson Behaviors & $\rightarrow$ & Usage Intention & $0.245^{* * *}$ & H6 & Supported \\
\hline Satisfaction & $\rightarrow$ & Usage Intention & $0.130 * *$ & $\mathrm{H} 7$ & Supported \\
\hline
\end{tabular}

\subsection{Mediation Effect Analysis}

There are three mediating effects in this study. Customers' satisfaction has a mediating effect on the mobile payment usage intention and the utilitarian value. Customers' satisfaction has a mediating effect on hedonic value and mobile payment usage intention. Customers' satisfaction has a mediating effect on salesperson selling behaviors and mobile payment usage intention.

In this study, the results of the Sobel test show that the result of values of this Sobel test are all greater than 1.96 (Sobel, 1982), and that all 95\% confidence intervals for 5000 simulation analyses through Bootstrapping analysis did not include 0 (Efron and Tibshirani, 1993) [73,74]. The study indicates that customer satisfaction has significant impacts on utilitarian value, hedonic value, salesperson selling behaviors and mobile payment usage intention (see Table 6).

Table 6. Sobel test and bootstrapping confidence interval of mediator effects.

\begin{tabular}{llcccccc}
\hline \multirow{2}{*}{ IV } & \multirow{2}{*}{$\mathbf{M}$} & DV & \multirow{2}{*}{ Sobel Test } & \multicolumn{3}{c}{ Bootstrapping 95\%Confidence I } \\
\cline { 5 - 7 } & & & & \multicolumn{2}{c}{ Percentile CI } & \multicolumn{2}{c}{ Biased Method CI } \\
\cline { 4 - 7 } & & & & Lower & Upper & Lower & Upper \\
\hline UV & PS & UI & 4.683 & 0.077 & 0.189 & 0.075 & 0.201 \\
HV & PS & UI & 3.898 & 0.032 & 0.0954 & 0.0351 & 0.117 \\
SSB & PS & UI & 3.9787 & 0.0516 & 0.1515 & 0.0548 & 0.513 \\
\hline
\end{tabular}

\section{Conclusions and Suggestions}

\subsection{Conclusions}

Empirical research shows that consumers' utilitarian value, hedonic value and salesperson selling behaviors positively affect customers' satisfaction, and Utilitarian value is considered to be an assessment of all the utilitarian costs and benefits. Hedonic value refers to the emotions about products, services and activities generated on the basis of hedonic activities, focusing on the experiences of the product purchasing process. For the first purpose, we can find that customer perceived value which comprises hedonic value and utilitarian value, also salesperson selling behaviors, all have positive impacts on customer satisfaction.

When people use mobile payment, they also enjoy the pleasure of consumption. The salesperson will explain the usage of mobile payment according to consumers' perception and will operate it to show to consumers. When consumers feel the behavior of the salesperson, their satisfaction will be 
relatively improved. Therefore, the perceived value which comprises hedonic value and utilitarian value and salesperson selling behavior has positively affected customers' satisfaction. In the part of customer satisfaction, this study finds that consumers' utilitarian value, hedonic value and salesperson selling behavior have positive impacts on customer satisfaction. This shows that customers tend to attach more importance to the acquisition of immediate benefits.

Many customers think that they will feel the existence of individual uniqueness at the moment of mobile payment, making them feel different from others, which will lead to the improvement of customer satisfaction. In terms of salesperson selling behavior, it can be clearly found that when consumption is made through mobile payment, the salesperson's introduction and assistance in actual operation will greatly improve customer satisfaction and will make the customers more likely to use mobile payment and consider mobile payment as one of the most critical options for payment. In short, when customers use the mobile payment function and consume through mobile payment, they will understand the satisfaction brought by mobile payment, and have relatively greater intention to use mobile payment. Consumer's perceived value, which comprises hedonic value and utilitarian value, comes from their perception. When consumers feel the convenience and happiness brought on by mobile payment, or feel the good performance of salesmen in the operation process, they will have greater intention to use mobile payment during consumption.

Therefore, operators can make use of the utilitarian value or hedonic value of mobile payment to create topics, encourage consumers to use mobile payment in consumption, and make use of the explanations of salesmen to make consumers more willing to use mobile payment. The mediating mechanism of customer satisfaction can assist the consumers' hedonic value and utilitarian value, the salesperson selling behaviors and the mobile payment usage intention.

The study finds that customer perceived value (utilitarian and hedonic) and salesperson selling behaviors can improve customer usage intention through customer satisfaction. It means that when promoting mobile payment products, the sellers shall first make customers free from vigilance towards the usage of mobile payment, so that customers can slowly tend towards mobile payment. In addition, they shall explain the mobile payment functions to customers. After trying the usage of mobile payment, customers can understand the convenience of mobile payment and experience the pleasant atmosphere brought by new payment means. In addition, if there is a salesperson to guide them, it can reduce customers' doubts about mobile payment and increase their mobile payment usage intention. Therefore, customer perceived value and salesperson selling behaviors can increase mobile payment usage intention through customer satisfaction.

\subsection{Suggestions}

1. Stores can share free Internet or WIFI and improve the security of mobile network transmission. Many consumers are less willing to use mobile payment because they do not have access to the Internet, or the signal is very weak during their consumption.

2. Business operators can adopt cross-industry alliances to provide more diversified and preferential promotion programs or lottery activities. Consumers will be more willing to use mobile payment if they can enjoy promotion programs together with lottery activities in consumption.

3. Business operators can strengthen the promotion and marketing of mobile payment through online social media. To popularize mobile payment, in addition to the cooperation and promotion of government policies, businesses operators can strengthen the promotion and marketing of mobile payment through online social media. The study finds that salesperson performance is significantly correlated with satisfaction. Because the mobile payment function is more reliable and faster, it is recommended that the company can regularly hold employee on-the-job training, so that employees can immediately operate it to reduce customers' waiting time. This study adopts the cross-section method, and that may be this study's main limitation, so it is only based on observing the data at a certain point in time as the basis for inference and verification. Therefore, it is impossible to understand 
the relationship between variables in the longitudinal section, and the inference and development of causality have limitations.

Author Contributions: Conceptualization and data curation: S.-C.C., formal analysis and methodology: K.C.C., writing-review and editing: M.Y.T.

Funding: This research received administrative and funding support from a project of Ministry of Education, R.O.C., Taiwan.

Conflicts of Interest: The authors declare no conflict of interest.

\section{References}

1. Institute for Information Industry. Taiwanese People Are More Sticky Phones! Nearly $80 \%$ of the People Use Mobile Phones Every Day for More Than 2 Hours. 2018. Available online: https://www.iii.org.tw/Press/ NewsDtl.aspx?nsp_sqno=2081\&fm_sqno=14 (accessed on 1 December 2018).

2. Statista. The Key to Mobile Payment and Electronic Payment. 2018. Available online: https://www.statista. com/study/39303mobile-payment-usage-worldwide/ (accessed on 2 December 2018).

3. Institute for Information Industry. Nearly $40 \%$ of Mobile Phone Users Have Used Mobile Payment Line Pay, Apple Pay Has the Highest Awareness. 2018. Available online: https://mic.iii.org.tw/news.aspx?id=486 (accessed on 1 December 2018).

4. Al-Sabbahy, H.Z.; Ekinci, Y.; Riley, M. An investigation of perceived value dimensions: Implications for hospitality research. J. Travel Res. 2004, 42, 226-234. [CrossRef]

5. Kulviwat, S.; Bruner, G.C.; Kumar, A.; Nasco, S.A.; Clark, T. Toward a unified theory of consumer acceptance technology. Psychol. Mark. 2007, 24, 1059-1084. [CrossRef]

6. Lee, C.P.; Warkentin, M.; Choi, H. The role of technological and social factors on the adoption of mobile payment technologies. In Proceedings of the 10th Americas Conference on Information Systems (AMCIS 2004), New York, NY, USA, 6-8 August 2004; pp. 2781-2786.

7. Lee, M.; Kim, Y.; Fairhurst, A. Shopping value in online auctions: Their antecedents and outcomes. J. Retail. Consum. Serv. 2009, 16, 75-82. [CrossRef]

8. Sharma, A. Does the salesperson like customers? A conceptual and empirical examination of the persuasive effect of perceptions of the salesperson's affect toward customers. Psychol. Mark. 1999, 16, 141-162. [CrossRef]

9. Wang, Y.S. Assessing e-commerce systems success: A respecification and validation of the DeLone and McLean model of IS success. Inf. Syst. J. 2008, 18, 529-557. [CrossRef]

10. Emarketer. 2018. Available online: https://www.emarketer.com/content/emarketer-releases-new-globalproximity-mobile-payment-figures (accessed on 1 December 2018).

11. Qin, Z.; Sun, J.; Wahaballa, A.; Zheng, W.; Xiong, H. A secure and privacy preserving mobile wallet with outsourced verification in cloud computing. Comput. Stand. Interfaces 2017, 54, 55-60. [CrossRef]

12. Kim, C.; Mirusmonov, M.; Lee, I. An empirical examination of factors influencing the intention to use mobile payment. Comput. Hum. Behav. 2010, 26, 310-322. [CrossRef]

13. Qasim, H.; Abu-Shanab, E. Drivers of mobile payment acceptance: The impact of network externalities. Inf. Syst. Front. 2015, 8, 1-14. [CrossRef]

14. Morosan, C.; DeFranco, A. It's about time: Revisiting UTAUT2 to examine consumers' intentions to use NFC mobile payments in hotels. Int. J. Hosp. Manag. 2016, 53, 17-29. [CrossRef]

15. Mehrabian, A.; Russell, J.A. An Approach to Environmental Psychology; MIT Press: Cambridge, MA, USA, 1974.

16. Jacoby, J. Stimulus-organism-response reconsidered: An evolutionary step in modeling (consumer) behavior. J. Consum. Psychol. 2002, 12, 51-57. [CrossRef]

17. Chan, T.K.; Cheung, C.M.; Lee, Z.W. The state of online impulse-buying research: A literature analysis. Inf. Manag. 2017, 54, 204-217. [CrossRef]

18. Chang, H.J.; Eckman, M.; Yan, R.N. Application of the stimulus-organism-response model to the retail environment: The role of hedonic motivation in impulse buying behavior. Int. Rev. Retail 2011, 21, 233-249. [CrossRef]

19. Hossain, M.S.; Zhou, X. Impact of m-payments on purchase intention and customer satisfaction: Perceived flow as mediator. Int. J. Sci. Bus. 2018, 2, 503-517.

20. Scarpi, D. Hedonic and utilitarian behaviour in specialty shops. Mark. Rev. 2005, 5, 31-44. [CrossRef] 
21. Babin, B.J.; Darden, W.R.; Griffin, M. Work and/or Fun: Measuring hedonic and utilitarian shopping value. J. Consum. Res. 1994, 20, 644-656. [CrossRef]

22. Ryu, K.; Han, H.; Jang, S. Relationships among hedonic and utilitarian values, satisfaction and behavioral intentions in the fast-casual restaurant industry. Int. J. Contemp. Hosp. Manag. 2010, 22, 416-432. [CrossRef]

23. Overby, J.W.; Lee, E.J. The effects of utilitarian and hedonic online shopping value on consumer preference and intentions. J. Bus. Res. 2006, 59, 1160-1166. [CrossRef]

24. Lowe, B.; Alpert, F. Forecasting consumer perception of innovativeness. Technovation 2015, 45-46, 1-14. [CrossRef]

25. Jong, U.K.; Woong, J.K.; Sang, C.P. Consumer perceptions on Web advertisements and motivation factors to purchase in the online shopping. Comput. Hum. Behav. 2010, 26, 1208-1222.

26. Roy, R.; Ng, S. Regulatory focus and preference reversal between hedonic and utilitarian consumption. J. Consum. Behav. 2012, 11, 81-88. [CrossRef]

27. Soman, D.T. The effect of payment transparency on consumption: Quasi-experiments from the field. Mark. Lett. 2003, 14, 173-183. [CrossRef]

28. Raghubir, P.; Srivastava, J. Monopoly money: The effect of payment coupling and form on spending behavior. J. Exp. Psychol. Appl. 2008, 14, 213-225. [CrossRef] [PubMed]

29. Chatterjee, P.; Rose, R.L. Do payment mechanisms change the way consumers perceive products? J. Consum. Res. 2012, 38, 1129-1139. [CrossRef]

30. Chitturi, R.; Raghunathan, R.; Mahajan, V. Form versus function: How the intensities of specific emotions evoked in functional versus hedonic trade-offs mediate product preferences. J. Mark. Res. 2007, 44, 702-714. [CrossRef]

31. Chitturi, R.; Raghunathan, R.; Mahajan, V. Delight by design: The role of hedonic versus utilitarian benefits. J. Mark. 2008, 72, 48-63. [CrossRef]

32. Jones, E.; Brown, S.P.; Zoltners, A.A.; Weitz, B.A. The changing environment of selling and sales management. J. Pers. Sell. Sales Manag. 2005, 25, 105-110.

33. Price, L.L.; Arnould, E.J.; Deibler, S.L. Consumers' emotional responses to service encounters: The influence of the service provider. Int. J. Serv. Ind. Manag. 1995, 6, 34-63. [CrossRef]

34. Siu, N.Y.M.; Cheung, J.T. A measure of retail service quality. Mark. Intell. Plan. 2001, 19, 88-97. [CrossRef]

35. Ahearne, M.; Jelinek, R.; Jones, E. Examining the effect of salesperson service behavior in a competitive context. J. Acad. Mark. Sci. 2007, 35, 603-616. [CrossRef]

36. Darian, J.C.; Wiman, A.R.; Tucci, L.A. Retail patronage intentions: The relative importance of perceived prices and salesperson service attributes. J. Retail. Consum. Serv. 2005, 12, 15-23. [CrossRef]

37. Johnson, M.S.; Sivadas, E.; Kashyap, V. Response bias in the measurement of salesperson orientations: The role of impression management. Ind. Mark. Manag. 2009, 38, 1014-1024. [CrossRef]

38. Rapp, A.; Bachrach, D.G.; Panagopoulos, N.; Ogilvie, J. Salespeople as knowledge brokers: A review and critique of the challenger sales model. J. Pers. Sell. Sales Manag. 2014, 34, 245-259. [CrossRef]

39. Lee, S.; Dubinsky, A. Influence of salesperson characteristics and customer emotion on retail dyadic relationships. Int. Rev. Retail Distrib. Consum. Res. 2003, 13, 23-36. [CrossRef]

40. Fishbein, M.; Ajzen, I. Belief, Attitude, Intention, and Behavior: An Introduction to Theory and Research; Addison-Wesley: Boston, MA, USA, 1975.

41. Fishbein, M.; Ajzen, I. Understanding Attitudes and Predicting Social Behavior; Prentice-Hall: Englewood Cliffs, NJ, USA, 1980.

42. Zeithaml, V.A.; Berry, L.L.; Parasuraman, A. The behavioral consequences of service quality. J. Mark. 1996, 60, 31-46. [CrossRef]

43. Taylor, S.; Todd, P.A. Understanding information technology usage: A test of competing models. Inf. Syst. Res. 1995, 6, 144-176. [CrossRef]

44. Zhang, X.; Prybutok, V.R. A consumer perspective of e-service quality. IEEE Trans. Eng. Manag. 2005, 52, 461-477. [CrossRef]

45. Lin, C.P.; Huang, H.N.; Joe, S.W.; Ma, H.C. Learning the determinants of satisfaction and usage intention of instant messaging. Cyber Psychol. Behav. 2008, 11, 262-267. [CrossRef] [PubMed]

46. Shin, D.H. Towards an understanding of the consumer acceptance of mobile wallet. Comput. Hum. Behav. 2009, 25, 1343-1354. [CrossRef] 
47. Turel, O.; Serenko, A.; Bontis, N. User acceptance of wireless short messaging services: Deconstructing perceived value. Inf. Manag. 2007, 44,63-73. [CrossRef]

48. DeSarbo, W.S.; Jedidi, K.; Sinha, I. Customer value analysis in a heterogeneous market. Strateg. Manag. J. 2001, 22, 845-857. [CrossRef]

49. Terpstra, M.; Verbeeten, F.H.M. Customer satisfaction: Cost driver or value driver? Empirical evidence from the financial services industry. Eur. Manag. J. 2014, 32, 499-508. [CrossRef]

50. Eggert, A.; Ulaga, W. Customer perceived value: A substitute for satisfaction in business markets. J. Bus. Ind. Mark. 2002, 17, 107-118. [CrossRef]

51. Hsu, H. An empirical study of web site quality, customer value, and customer satisfaction based on e-shop. Bus. Rev. 2006, 5, 190-193.

52. Oliver, R.L. Satisfaction: A Behavioral Perspective on the Consumer; Routledge: New York, NY, USA, 2014.

53. Yoo, W.S.; Lee, Y.; Park, J. The role of interactivity in e-tailing: Creating value and increasing satisfaction. J. Retail. Consum. Serv. 2010, 17, 89-96. [CrossRef]

54. Amyx, D.; Bhuian, S. Salesperf: The salesperson service performance scale. J. Pers. Sell. Scdes Manag. 2009, 29, 367-376. [CrossRef]

55. Román, S.; Juan Martín, P. Does the hierarchical position of the buyer make a difference? The influence of perceived adaptive selling on customer satisfaction and loyalty in a business-to-business context. J. Bus. Ind. Mark. 2014, 29, 364-373. [CrossRef]

56. Román, S.; Iacobucci, D. Antecedents and consequences of adaptive selling confidence and behavior: A dyadic analysis of salespeople and their customers. J. Acad. Mark. Sci. 2009, 38, 363-382. [CrossRef]

57. Bridges, E.; Florsheim, R. Hedonic and utilitarian shopping goals: The online experience. J. Bus. Res. 2008, 61, 309-314. [CrossRef]

58. Pihlstrom, M.; Brush, G.J. Comparing the perceived value of information and entertainment moible services. Psychol. Mark. 2008, 25, 732-755. [CrossRef]

59. Pilling, B.K.; Eroglu, S. An empirical examination of the impact of salesperson empathy and professionalism and merchandise slability on retail buyers evaluations. J. Pers. Sell. Sales Manag. 1994, 14, 45-58.

60. Kennedy, M.S.; Ferrell, L.K.; LeClair, D.T. Consumers' trust of salesperson and manufacturer: An empirical study. J. Bus. Res. 2001, 51, 73-86. [CrossRef]

61. Haas, A.; Kenning, P. Utilitaria and hedonic motivators of shoppers' decision to consult with salespeople. J. Retail. 2014, 90, 428-441. [CrossRef]

62. Sun, T.R.; Yazdanifard, R. Review of physical store factors that influence impulsive buying behavior. Int. J. Manag. Account. Econ. 2015, 2, 1048-1054.

63. Chea, S.; Luo, M.M. Post-adoption behaviors of e-service customers: The interplay of cognition and emotion. Int. J. Electron. Commer. 2008, 12, 29-56. [CrossRef]

64. Anderson, E.W.; Sullivan, M.W. The antecedents and consequences of customer satisfaction for firms. Mark. Sci. 1993, 12, 125-143. [CrossRef]

65. Gotlieb, J.B.; Grewal, D.; Brown, S.W. Consume. satisfaction and perceived quality: Complementary or divergent constructs? J. Appl. Psychol. 1994, 79, 875-885. [CrossRef]

66. Chou, S.W.; Min, H.T.; Chang, Y.C.; Lin, C.T. Understanding continuance intention of knowledge creation using extended expectation-confirmation theory: An empirical study of Taiwan and China online communities. Behav. Inf. Technol. 2010, 29, 557-570. [CrossRef]

67. Chen, S.C.; Yen, D.C.; Hwang, M.I. Factors influencing the continuance intention to the usage of Web 2.0. Comput. Hum. Behav. 2012, 28, 933-941. [CrossRef]

68. Chen, J.H.; Fu, J.R. On the effects of perceived value in the mobile moment. Electron. Commer. Res. Appl. 2018, 27, 118-128. [CrossRef]

69. Escobar-Rodríguez, T.; Carvajal-Trujillo, E. Online purchasing tickets for low cost carriers: An application of the unified theory of acceptance and use of technology (UTAUT) model. Tour. Manag. 2014, 43, 70-88. [CrossRef]

70. Schierz, P.G.; Schilke, O.; Wirtz, B.W. Understanding consumer acceptance of mobile payment services: An empirical analysis. Electron. Commer. Res. Appl. 2010, 9, 209-216. [CrossRef]

71. Gaski, J.F.; Nevin, J.R. The differential effects of exercised and unexercised power sources in a marketing channel. J. Mark. Res. 1985, 22, 130-142. [CrossRef] 
72. Fornell, C.R.; Larcker, F.F. Structural equation models with unobservable variables and measurement error. J. Mark. Res. 1981, 18, 39-51. [CrossRef]

73. Sobel, M.E. Asymptotic confidence intervals for indirect effects in structural equation models. Sociol. Methodol. 1982, 13, 290-312. [CrossRef]

74. Efron, B.; Tibshirani, R.J. An Introduction to the Bootstrap; Chapman and Hall: London, UK, 1993.

(C) 2019 by the authors. Licensee MDPI, Basel, Switzerland. This article is an open access article distributed under the terms and conditions of the Creative Commons Attribution (CC BY) license (http://creativecommons.org/licenses/by/4.0/). 